\title{
Appraisal of the retention of the knowledge for ophthalmology specialists of the Brazilian Ophthalmology Council
}

\author{
A valiação da retenção deconhecimentode oftalmologistas com títulode especialista \\ pelo Conselho Brasileiro de Oftalmologia
}

\author{
Paulo Henrique Limeira-Soares \\ Rodrigo Pessoa Cavalcanti Lira ${ }^{2}$ \\ Marcelo Paccola ${ }^{3}$ \\ Carlos Eduardo Leite Arieta ${ }^{4}$
}

\begin{tabular}{l} 
ABSTRACT \\
\hline Purpose: To determine the retention of knowledge along the years after \\
certification of physicians as ophthalmology specialists. Methods: The \\
physicians, former ophthalmology residents, were selected at the De- \\
partment of Ophthalmology, State University of Campinas, São Paulo, \\
Brazil, and randomly allocated to three groups of seven individuals, \\
according to the time as specialists. Group 1 consisted of one-year \\
specialists, group 2 of five-year specialists and group 3 of ten-year \\
specialists. Each participant answered a test with twenty-five multiple \\
choice randomly selected questions, based on the national certificate \\
tests applied by the Brazilian Ophthalmology Council between 1994 and \\
2003. Each question scored four points. Results: The mean age of groups \\
1,2 and 3 was 27,30 and 36years, respectively. A preponderance of males \\
was found in all groups. Group 1 achieved the highest score, average of \\
88, group 2 achieved 77, and group 3 achieved the lowest, average of 64 \\
(p<0,05). Conclusion: Loss of knowledge retention amongst specialists \\
of the Brazilian Ophthalmology Council, has been observed along the \\
years after the certification.
\end{tabular}

Keywords: Education, Medical, Continuing; Clinical competence; Ophthalmology; Randomized controlled trials; Brazilian Ophthalmology Council

\section{INTRODUCTION}

In the past few years, continuing medical education has gained evidence as a result of an increasing effort to offer a better quality in medical services and more favorable patient outcomes ${ }^{(1-2)}$. In order to fulfill this educational claim, the Brazilian Ophthalmology Council has prepared a recertification program for ophthalmology specialists of the Board ${ }^{(3)}$. Recertification will be instituted in an attempt to ensure that specialists remain updated regarding new clinical and surgical knowledge in ophthalmology. Our Department offers valuable opportunities for continuing education to help the ophthalmologists to keep abreast of courses and meetings of interest. However, the effectiveness of such actions has not yet been established ${ }^{2}$, therefore a whole new field of research has been brought to light.

The following analysis aims to determine the retention of knowledge along the years after certification of physicians as ophthalmology specialists and it highlights many difficulties to set a definite policy for continuing education in ophthalmology. 


\section{METHODS}

The present report was elaborated as a pretest survey analysis, in which the included physicians were selected at the Department of Ophthalmology, State University of Campinas, from November 2003 to August 2004. The inclusion criteria were as follows: (1) former ophthalmology resident at the Department of Ophthalmology, School of Medical Sciences, State University of Campinas, São Paulo, Brazil; (2) ophthalmologists who attended Annual Ophthalmology International Congresses sponsored by the Department of Ophthalmology at least in the three last years; (3) ophthalmologists who attend at least one weekly meeting at the Department in any subspecialty; and (4) ophthalmologists who develop either clinical and/or surgical resident teaching activity at our Department.

They were randomly allocated to three groups of seven individuals, according to the time as specialists. Group 1 consisted of 1-year specialists, group 2 of five-year specialists and group 3 of ten-year specialists. Each participant answered a written test in Portuguese with twenty-five multiple choice randomly selected questions, based on the national certificate test applied by the Brazilian Ophthalmology Council between 1994 and 2003, embracing topics in glaucoma, retinal diseases, external ocular diseases, lacrimal apparatus and plastic surgery, refraction, strabismus and low-vision care. The tests were answered individually; each question scored four points and had to be completed in one minute. The results were submitted to statistical analysis by the Statistical Program for Social Sciences (SPSS) version 10.0 and tabulated.

\section{RESULTS}

The mean age of the groups 1, 2 and 3 was 27, 30 and 36 years, respectively. Preponderance of males was found to be similar in all groups, $85.71 \%(6)$.

Table 1 shows the test scores achieved individually in each group and the average result obtained by each group. Group 1 (one-year specialists) achieved the highest score, average of 88, group 2 (five-year specialists) achieved 77, and group 3 (ten-year specialists) achieved the lowest, average of

\begin{tabular}{|cccc|}
\hline \multicolumn{4}{|c|}{ Table 1. Distribution of achieved scores among the three groups } \\
Group 1 & Group 2 & Group 3 \\
92 & 88 & 69 \\
84 & 67 & 56 \\
84 & 68 & 88 \\
& 92 & 92 & 68 \\
& 76 & 80 & 52 \\
Mean & 92 & 76 & 40 \\
& 96 & 68 & 76 \\
\hline
\end{tabular}

64. As can be seen, neither group 1, nor group 2, had individual scores below 67; on the other hand, three individual scores in group 3 were below 60 .

Further analysis demonstrated that the reduction in the average scores, between groups 1 and 3 were statistically significant $(\mathrm{p}<0.05)$.

\section{DISCUSSION}

The fact that retention of theoretical knowledge showed a progressive decline along the years after the specialty certification, raises a number of important questions concerning the up to now currently used methods, regarding continuing medical education in ophthalmology.

Of course one shall consider that, many professionals have dedicated more of their time getting to the depth of their subareas of practice but, is it what patients really need ${ }^{(4-5)}$ ?

The information brought out by this study should, though, be carefully analyzed as we have assessed only a momentary, restricted matter involved in continuing education. Despite the statistical significance of the obtained results, further and more extensive investigation must be conducted in order to embrace many individual and cluster aspects involved in the process of learning and retaining medical contents along the years.

The recertification program proposed by the Brazilian Ophthalmology Council is an attempt to provide a better qualified professional. Our analysis showed results that corroborate this essential need, although we are not certain if this is the best way to do it, for, again, only one part of ophthalmologic practice will be contemplated. Even if not assessed by this study, patients' outcomes and physician-patient relationship must be considered, not only in providing excellence in ophthalmology practice but in continuing medical education itself.

\section{CONCLUSIONS}

As assessed by this report, we have observed a loss of knowledge retention amongst specialists of the Brazilian Ophthalmology Council, along the years after the certification, in spite of all efforts made towards a closer contact with the latest issues in the specialty, by means of courses, meetings and other activities.

\section{RESUMO}

Objetivo: Determinar a retenção de conhecimento teórico ao longo dos anos, após a aprovação para o título de especialista em oftalmologia. Métodos: Foram selecionados aleatoriamente três grupos, com sete médicos cada, entre ex-residentes do Departamento de Oftalmologia da Universidade Estadual de 
Campinas. Os médicos do grupo 1 tinham sido aprovados para o título de especialista em oftalmologia do Conselho Brasileiro de Oftalmologia (CBO) há um ano, os do grupo 2 há cinco anos e os do grupo 3 há dez anos. Cada oftalmologista respondeu um teste escrito composto por 25 questões escolhidas aleatoriamente entre as provas aplicadas pelo CBO entre os anos 1994 e 2003. Cada questão valeu 4 pontos de um total de 100 possíveis. Resultados: A média de idade dos grupos 1, 2 e 3 foi de 27,30 e 36 anos, respectivamente. Preponderância do sexo masculino ocorreu em todos os grupos. A média de acertos do grupo 1 foi de 88 pontos, do grupo 2 foi de 77 pontos e do grupo 3 foi de 64 pontos $(\mathrm{p}<0,05)$. Conclusões: Houve diminuição significativa da retenção de conhecimento teórico ao longo dos anos, após a aprovação para o título de especialista em oftalmologia.
Descritores: Educação médica continuada; Competência clínica; Oftalmologia; Ensaios controlados aleatórios; Conselho Brasileiro de Oftalmologia

\section{REFERENCES}

1. Davis DA, Thomson MA, Oxman AD, Haynes RB. Evidence for the effectiveness of CME. A review of 50 randomized controlled trials. JAMA. 1992; 268(9):1111-7.

2. Davis DA, Thomson MA, Oxman AD, Haynes RB. Changing physician performance. A systematic review of the effect of continuing medical education strategies. JAMA. 1995;274(9):700-5.

3. Novo Programa de Educação Médica Continuada em Oftalmologia à distância do CBO [Notas]. Arq Bras Oftalmol. 2004;67(1):186.

4. Bass MJ, McWhinney IR, Donner A. Do family physicians need medical assistants to detect and manage hypertension? CMJA.1986;134(11):1247-55.

5. Rayner C. A patient's eye view of quality. BMJ. 1999;319(7208):525.

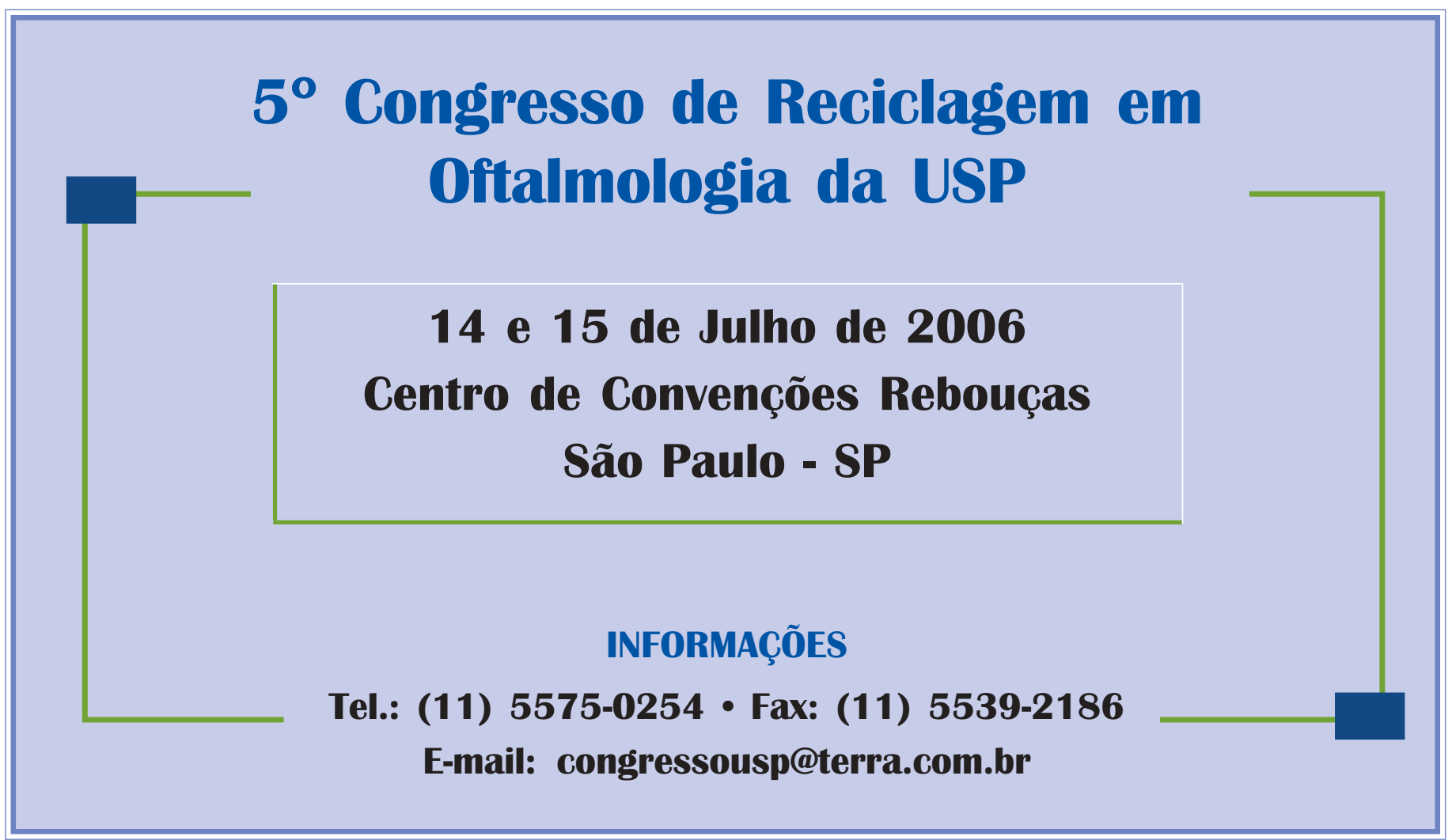

